\title{
Efficacy and Safety of Tiotropium in Children and Adolescents
}

\author{
Eckard Hamelmann ${ }^{1} \cdot$ Stanley J. Szefler ${ }^{2,3}$
}

Published online: 24 January 2018

(C) The Author(s) 2018. This article is an open access publication

\begin{abstract}
Asthma is one of the most common chronic diseases in children, with a high proportion of patients demonstrating poor control despite the availability of disease management guidelines. Global Initiative for Asthma guidelines include tiotropium as an add-on therapy option at Steps 4 and 5 in patients aged $\geq 12$ years with a history of exacerbations, and tiotropium delivered via the Respimat $^{\circledR}$ Soft Mist ${ }^{\mathrm{TM}}$ Inhaler has recently been approved for use as once-daily maintenance therapy for children with asthma over the age of 6 years in the USA. A large clinical trial program has been conducted in children, adolescents, and adults across the spectrum of asthma severity. Findings from these clinical studies and pooled analyses in children and adolescents with symptomatic moderate or severe asthma have demonstrated that tiotropium Respimat ${ }^{\circledR}$ as add-on to inhaled corticosteroids, with or without other maintenance therapies, is a well-tolerated and efficacious bronchodilator, showing improved lung function and trends towards improved asthma control, mirroring findings in adult studies. This review discusses the evidence to date for tiotropium Respimat ${ }^{\circledR}$ for the management of asthma in adolescents and children with symptomatic moderate and severe asthma, and considers the challenges of asthma management in these patients. Factors affecting this population group, such as poor adherence, underreporting of
\end{abstract}

Eckard Hamelmann

Eckard.Hamelmann@evkb.de

1 Children's Center Bethel, Evangelisches Klinikum Bethel GmbH, Grenzweg 10, 33617 Bielefeld, Germany

2 Department of Pediatrics, University of Colorado School of Medicine, Aurora, USA

3 Breathing Institute, Children's Hospital Colorado, Aurora, USA symptoms, and social and psychological issues, are highlighted, along with the need for active review and management of treatment to help achieve optimal control.

\section{Key Points}

Poorly controlled asthma is common in children and adolescents.

Tiotropium Respimat ${ }^{\circledR}$ can help improve a patient's asthma when added to other controller options.

It is important to understand the factors that contribute to poor asthma control in children and adolescents, and for patients, carers, and physicians to work together to overcome these challenges.

\section{Introduction}

Asthma affects approximately 235 million people worldwide [1], and is one of the most common chronic diseases observed in children, concerning approximately one in 11 children in the UK [2] and $10 \%$ of adolescents aged 12-18 years in USA [3]. Despite the availability of national and international asthma management guidelines [4], up to 50\% of patients aged 4-18 years with asthma show symptoms as signs of inadequate control [3]. Poor control not only contributes to high treatment costs, but is also associated with more frequent exacerbations and an increased risk of persistent asthma in children $[5,6]$.

Therefore, there is a need for effective and well-tolerated treatment options for those patients who have 
difficulty gaining and maintaining disease control. The long-term goals of asthma management in children and adolescents are quite similar to those in adults, and include achieving good symptom control, minimizing the risk of asthma exacerbations, reducing hospitalizations, reducing the use of rescue medication, reducing airflow limitation and side effects, and allowing maintenance of normal activity levels [4].

Using the Global Initiative for Asthma (GINA) approach to asthma management, therapy in children and adolescents is stepped up from initial, on-demand shortacting beta agonists (SABAs) through a backbone of inhaled corticosteroids (ICS) at increasing doses as maintenance therapy. The first-line escalation after increasing to medium-dose ICS involves the addition of either a longacting $\beta_{2}$-agonist (LABA) or a leukotriene receptor antagonist (LTRA), or further increasing to high-dose ICS. This is followed by the addition of a long-acting muscarinic antagonist (LAMA) [tiotropium] or biologic treatments (e.g., omalizumab) for patients with severe asthma with sensitization against perennial allergens, and finally, and only in cases of severe exacerbations or lasting loss of asthma control, oral corticosteroids [4]. Treatment recommendations may vary from country to country and should be followed based on local approval for the different drugs. Guidelines for management in individuals aged $0-5$ years, as well those aged 6-11 years, differ from those for adolescents, with more limited therapeutic options than in adolescents and adults [4]. Especially for younger patients with partially or uncontrolled asthma, therapeutic options have been quite limited to date.

Tiotropium is a LAMA that primarily acts as a bronchodilator. The GINA guidelines include tiotropium delivered by mist inhaler as an add-on therapy option at Steps 4 and 5 in patients aged $\geq 12$ years with a history of exacerbations despite treatment with ICS and LABAs [4], and tiotropium Respimat ${ }^{\circledR}$ (Boehringer Ingelheim, Ingelheim am Rhein, Germany) has recently been approved for use as once-daily maintenance therapy for children with asthma over the age of 6 years in the USA (February 2017). The aim of this review is to discuss the evidence to date, demonstrating the efficacy and safety of tiotropium in children and adolescents, and to consider the asthma management challenges specific to this population group.

\section{Anticholinergic Agents in Asthma Management}

Experience with anticholinergic bronchodilators in asthma is well documented. Ipratropium bromide, a short-acting muscarinic antagonist, has been used in clinical practice for many years [4, 7] as a rapid bronchodilator in acute exacerbations of asthma in children and adolescents $[8,9]$.
For children and adults with moderate-to-severe exacerbations, treatment with a combination of ipratropium and a SABA are reported to be associated with fewer hospitalizations, and a greater improvement in forced expiratory volume in $1 \mathrm{~s}\left(\mathrm{FEV}_{1}\right)$ and peak expiratory flow (PEF) compared with a SABA alone $[9,10]$. However, ipratropium is less effective in stable disease, adding only little additional bronchodilatory effect to regular SABAs or LABAs, and is therefore not recommended for daily or maintenance therapy [4].

Tiotropium, a long-acting form of anticholinergic bronchodilator, has been indicated for the treatment of chronic obstructive pulmonary disease for over 10 years, followed by its more recent approval for use in patients with asthma. Once-daily tiotropium delivered as two puffs via the Respimat ${ }^{\circledR}$ Soft Mist ${ }^{\mathrm{TM}}$ Inhaler is included in the most recent version of the GINA guidelines for asthma as a treatment option for addition to ICS plus LABAs at Steps 4 and 5 in adolescents and adults (aged $\geq 12$ years) with a history of exacerbations [4]. Tiotropium is the only LAMA approved for asthma in USA (patients aged $\geq 6$ years), Japan (patients aged $\geq 15$ years), and in Singapore and the European Union (patients aged $\geq 18$ years).

\subsection{Cholinergic Activity in Asthma and Mechanism of Action}

Tiotropium is well established for the management of chronic obstructive pulmonary disease, and the mechanism of action in the airways has been extensively studied. Acetylcholine, released from the parasympathetic nerves in the lungs, plays a significant role in the pathophysiology of asthma by increasing cholinergic tone and driving bronchial smooth muscle contraction [11-13]. Release of acetylcholine regulates airway tone, airway smooth muscle contraction, mucus secretion, and vasodilation via interactions with $\mathrm{G}$ protein-coupled muscarinic (M) receptors on the airway smooth muscle, glands, and pulmonary vasculature of the lungs $[12,14]$. There are three types of muscarinic receptors $\left(\mathrm{M}_{1}, \mathrm{M}_{2}\right.$, and $\left.\mathrm{M}_{3}\right)$ in the airways (Table 1). $\mathrm{M}_{1}$ receptors are expressed on postganglionic nerves in the ganglia and by airway epithelial cells, where they have a modulatory role in electrolyte and water secretion. $\mathrm{M}_{2}$ receptors have an inhibitory auto-regulatory effect on the release of acetylcholine from both pre- and postganglionic nerve terminals, but are also widely expressed by other cells such as fibroblasts and smooth muscle cells [15]. $\mathbf{M}_{3}$ receptors mediate the effects of acetylcholine on airway smooth muscle tone and mucus secretion from mucosal glands. Tiotropium binds equally well to $\mathrm{M}_{1}, \mathrm{M}_{2}$, and $\mathrm{M}_{3}$ receptors, but dissociates slowly from the $M_{1}$ and $M_{3}$ anticholinergic receptors, hence the long duration of bronchodilatory effect [16-18]. Thus, 
Table 1 Overview of muscarinic receptors in the airways $[15,72,73]$

\begin{tabular}{|c|c|c|c|}
\hline Receptor & Location & Mode of action & Function \\
\hline $\mathrm{M}_{1}$ & $\begin{array}{l}\text { Parasympathetic nerves } \\
\text { Submucosal glands } \\
\text { Airway epithelium }\end{array}$ & Typically couples to $\mathrm{G} \alpha \mathrm{q} / 11^{\mathrm{a}}$ & $\begin{array}{l}\text { Enhances neurotransmission } \\
\text { Increases ciliary beat frequency }\end{array}$ \\
\hline $\mathrm{M}_{2}$ & $\begin{array}{l}\text { Parasympathetic nerves } \\
\text { Smooth muscle cells } \\
\text { Endothelial cells } \\
\text { Airway epithelium }\end{array}$ & Typically couples to $\mathrm{G} \alpha \mathrm{i} / \mathrm{o}^{\mathrm{b}}$ & $\begin{array}{l}\text { Decreases neurotransmission } \\
\text { Limits acetylcholine release } \\
\text { Reduces ciliary beat frequency }\end{array}$ \\
\hline $\mathrm{M}_{3}$ & $\begin{array}{l}\text { Smooth muscle cells } \\
\text { Submucosal glands } \\
\text { Pulmonary arteries } \\
\text { Endothelial cells } \\
\text { Airway epithelium }\end{array}$ & Typically couples to $\mathrm{G} \alpha \mathrm{q} / 11^{\mathrm{a}}$ & $\begin{array}{l}\text { Bronchoconstriction } \\
\text { Mucus secretion } \\
\text { Vasodilation } \\
\text { Increases ciliary beat frequency }\end{array}$ \\
\hline
\end{tabular}

$M$ muscarinic

${ }^{a}$ Heterotrimeric $\mathrm{G}$ protein subunit that activates phospholipase $\mathrm{C}$

${ }^{b}$ Heterotrimeric $\mathrm{G}$ protein subunit that inhibits the production of cyclic adenosine monophosphate from adenosine triphosphate muscarinic antagonists facilitate bronchodilation by a different and potentially complementary mechanism to LABAs [19].

Aside from its impact as a bronchodilator, data suggest that tiotropium may have an inhibitory effect on airway remodeling, in addition to anti-inflammatory properties $[19,20]$. It has been suggested from in-vitro and in-vivo studies that tiotropium may have a direct anti-inflammatory effect, potentially via the suppression of proinflammatory cell activity, in addition to an indirect effect on suppression of airway smooth muscle contraction, thus reducing inflammatory activity [21]. Tiotropium has also been shown to reduce airway inflammation and T-helper-2 cytokine production in the bronchoalveolar lavage fluid in mouse models of allergic asthma [22, 23].

\section{Efficacy and Safety of Tiotropium across a Range of Asthma Severities}

\subsection{Established Efficacy and Safety of Tiotropium in Adults}

The efficacy and safety of tiotropium have been investigated in several phase II and III clinical studies in patients with symptomatic asthma, and have been discussed previously [24, 25]. Overall, six phase III studies have been conducted to assess the efficacy and safety of once-daily tiotropium $2.5 \mu \mathrm{g}$ and/or $5 \mu \mathrm{g}$ vs. placebo in adult patients with symptomatic mild (GraziaTinA-asthma ${ }^{\circledR}$ ) [26], moderate (MezzoTinA-asthma ${ }^{\circledR}$; CadenTinA-asthma $\left.{ }^{\circledR}\right)[27,28]$ or severe (PrimoTinA-asthma ${ }^{\circledR}$ ) [29] asthma as an add-on therapy to ICS (low-to-high dose) with or without LABAs.
Tiotropium add-on therapy has been associated with a significant reduction in the risk of exacerbations [29], as well as with improvements in lung function and asthma control [27] vs. placebo in symptomatic moderate or severe asthma. Furthermore, effect sizes with tiotropium are similar to effect sizes reported with salmeterol as add-on to ICS [27]. In a pooled safety analysis of data from studies in adults, the proportion of patients reporting adverse events (AEs), including serious AEs, was comparable between tiotropium and placebo groups [30]. As a consequence of these significant effects and a reassuring safety profile, tiotropium gained the approval for use in asthma management, as detailed above.

\subsection{Efficacy and Safety of Tiotropium in Adolescents and Children}

In addition to studies in adults, the efficacy and safety of tiotropium delivered via Respimat ${ }^{\circledR}$ has been investigated in a large-scale clinical trial program in adolescents and children with asthma. Phase II, randomized, dose-ranging studies of tiotropium at 5,2.5, and $1.25 \mu \mathrm{g}$ in adolescents aged 12-17 years [31] and children aged 6-11 years [32] with symptomatic asthma despite maintenance treatment with at least ICS have demonstrated the efficacy and safety of tiotropium in these groups. Phase III clinical studies in adolescents (aged 12-17 years) [33, 34] and children (aged 6-11 years) $[35,36]$ with symptomatic moderate-to-severe asthma have been conducted to assess the efficacy and safety of once-daily tiotropium 5 and $2.5 \mu \mathrm{g}$ vs. placebo as add-on therapy to treatment, including ICS (low-to-high dose) with or without additional controllers (Table 2). In each study, the primary endpoint was the change from 
Table 2 Overview of phase III studies with tiotropium Respimat ${ }^{\circledR}$ in adolescents and children

\begin{tabular}{|c|c|c|c|c|}
\hline & Asthma severity & Treatment duration, weeks & Baseline therapy & Treatment group, $n^{\mathrm{a}}$ \\
\hline \multicolumn{5}{|l|}{ Adolescents (aged 12-17 years) } \\
\hline RubaTinA-asthma $^{\circledR}$ (NCT01257230) [33] & $\begin{array}{l}\text { Symptomatic } \\
\text { moderate }\end{array}$ & 48 & At least ICS & $\begin{array}{l}\text { Tio } 5 \mu \mathrm{g}, 134 \\
\text { Tio } 2.5 \mu \mathrm{g}, 125 \\
\text { Placebo, } 138\end{array}$ \\
\hline $\begin{array}{l}\text { PensieTinA-asthma }{ }^{\circledR} \text { (NCT01277523) } \\
{[34]}\end{array}$ & Symptomatic severe & 12 & $\begin{array}{l}\text { ICS }+\geq 1 \\
\text { controller }\end{array}$ & $\begin{array}{l}\text { Tio } 5 \mu \mathrm{g}, 130 \\
\text { Tio } 2.5 \mu \mathrm{g}, 127 \\
\text { Placebo, } 135\end{array}$ \\
\hline \multicolumn{5}{|l|}{ Children (aged 6-11 years) } \\
\hline CanoTinA-asthma $^{\circledR}$ (NCT01634139) [35] & $\begin{array}{l}\text { Symptomatic } \\
\text { moderate }\end{array}$ & 48 & At least ICS & $\begin{array}{l}\text { Tio } 5 \mu \mathrm{g}, 135 \\
\text { Tio } 2.5 \mu \mathrm{g}, 135 \\
\text { Placebo, } 131\end{array}$ \\
\hline VivaTinA-asthma $^{\circledR}$ (NCT01634152) [36] & Symptomatic severe & 12 & $\begin{array}{l}\text { ICS }+\geq 1 \\
\text { controller }\end{array}$ & $\begin{array}{l}\text { Tio } 5 \mu \mathrm{g}, 130 \\
\text { Tio } 2.5 \mu \mathrm{g}, 136 \\
\text { Placebo, } 134\end{array}$ \\
\hline \multicolumn{5}{|l|}{ Children (aged 1-5-years) } \\
\hline NinoTinA-asthma $^{\circledR}$ (NCT01634113) [37] & $\begin{array}{l}\text { Persistent asthmatic } \\
\text { symptoms }\end{array}$ & 12 & At least ICS & $\begin{array}{l}\text { Tio } 5 \mu \mathrm{g}, 31 \\
\text { Tio } 2.5 \mu \mathrm{g}, 36 \\
\text { Placebo, } 34\end{array}$ \\
\hline
\end{tabular}

ICS inhaled corticosteroids, Tio tiotropium

${ }^{\mathrm{a}}$ Delivered as two puffs once daily via the Respimat ${ }^{\circledR}$

baseline in peak $\mathrm{FEV}_{1}$ within $3 \mathrm{~h}$ post-dose $\left[\mathrm{FEV}_{1(0-3 \mathrm{~h})}\right]$. Secondary endpoints included trough $\mathrm{FEV}_{1}$ response (change from baseline pre-dose $\mathrm{FEV}_{1}$ ), the 7-question Asthma Control Questionnaire (ACQ-7) score, and the interviewer-administered Asthma Control Questionnaire (ACQ-IA) score in 6- to 11-year-old children. In addition, severe exacerbations were defined as asthma worsening that required treatment with systemic (including oral) corticosteroids for 3 consecutive days or more. Asthma worsening was defined as either a progressive increase in one or more asthma symptoms outside the patient's usual range of day-to-day asthma (as determined by the study site investigator) and lasting for 2 or more consecutive days, or a decrease in the best morning PEF response of $30 \%$ or more of the mean morning response for 2 or more consecutive days.

A further study has recently been published evaluating the efficacy and safety of tiotropium in preschool children (aged 1-5 years) with persistent asthmatic symptoms (Table 2) [37]. The efficacy and safety of tiotropium addon therapy in school-age children and adolescents with symptomatic moderate-to-severe asthma has also been reported in systematic literature reviews [38, 39]. It is noteworthy to add that in tiotropium trials in adolescents and children, only lung function endpoints were confirmatory, symptom and exacerbation endpoints were assessed in an exploratory manner. Therefore, for the latter endpoints, the trials were not powered to show statistical significance.

\subsubsection{Symptomatic Moderate Asthma}

In the RubaTinA-asthma ${ }^{\circledR}$ study, adolescents with symptomatic moderate asthma were randomized to receive tiotropium Respimat ${ }^{\circledR} 5$ or $2.5 \mu \mathrm{g}$, or placebo Respimat ${ }^{\circledR}$ over 48 weeks as add-on therapy to ICS (200-800 $\mu \mathrm{g}$ of budesonide or equivalent in patients aged 12-14 years; $400-800 \mu \mathrm{g}$ in patients aged 15-17 years) with or without an LTRA (Table 2) [33]. Findings demonstrated that tiotropium add-on therapy improves lung function in adolescent patients with moderate asthma. Improvement in $\mathrm{FEV}_{1(0-3 \mathrm{~h})}$ after dosing at week 24 was statistically significant with both tiotropium doses compared with placebo: $5 \mu \mathrm{g}$ of tiotropium, adjusted mean difference $174 \mathrm{~mL}[95 \%$ confidence interval (CI) 76-272; $p<0.001]$; $2.5 \mu \mathrm{g}$ of tiotropium, $134 \mathrm{~mL}$ (95\% CI 34-234; $p<0.01)$. A statistically significant improvement in trough $\mathrm{FEV}_{1}$ was observed for tiotropium $5 \mu \mathrm{g}$ compared with placebo. At least one severe exacerbation was reported by two $(1.5 \%)$, five $(4.0 \%)$, and nine $(6.5 \%)$ patients treated with tiotropium 5, $2.5 \mu \mathrm{g}$, and placebo, respectively. Considering asthma worsening, at least one episode was reported for 30 
(22.4\%), $34(27.2 \%)$, and $37(26.8 \%)$ patients receiving tiotropium 5, $2.5 \mu \mathrm{g}$, and placebo, respectively. ACQ-7 scores at week 24 were numerically lower (improved control) with tiotropium compared with placebo, but the differences were not significant.

The efficacy and safety of once-daily tiotropium as an add-on therapy in children (aged 6-11 years) with moderate persistent asthma on medium-dose ICS (200-400 $\mu \mathrm{g} /$ day) was investigated in the CanoTinAasthma ${ }^{\circledR}$ study over 48 weeks (Table 2) [35, 40]. A significant improvement in $\mathrm{FEV}_{1(0-3 \mathrm{~h})}$ at week 24 was observed with both doses of tiotropium ( 5 and $2.5 \mu \mathrm{g}$ ), with adjusted mean differences of $164 \mathrm{~mL}$ (95\% CI 103-225) and $170 \mathrm{~mL}(95 \%$ CI 108-231) vs. placebo, respectively ( $p<0.0001$ for both comparisons). Statistically significant improvements were also seen in trough $\mathrm{FEV}_{1}$ at week 24 for both doses $(p<0.01)$. Severe asthma exacerbations and the number of patients reporting episodes of worsening occurred more frequently with placebo compared with tiotropium. Findings suggested that once-daily tiotropium as an add-on to maintenance therapy is safe and well tolerated in this patient group [40].

A subsequent pooled analysis involving 798 adolescents (RubaTinA-asthma ${ }^{\circledR}$ ) [33] and children (CanoTinAasthma ${ }^{\circledR}$ ) [35] with symptomatic moderate asthma reported similar findings to the adult studies [41]. Statistically significant improvements in peak $\mathrm{FEV}_{1(0-3 \mathrm{~h})}$ responses vs. placebo at week 24 were observed for both doses of tiotropium ( $p<0.0001$ for each comparison). The improvements observed in trough $\mathrm{FEV}_{1}$ responses vs. placebo at week 24 for both tiotropium doses were also statistically significant ( $p<0.01$ for each comparison). The differences were $>150 \mathrm{~mL}$ in peak $\mathrm{FEV}_{1(0-3 \mathrm{~h})}$ response and $>100 \mathrm{~mL}$ in trough $\mathrm{FEV}_{1}$ response vs. placebo (Table 3). The significant improvements in peak $\mathrm{FEV}_{1(0-3 \mathrm{~h})}$ and trough $\mathrm{FEV}_{1}$ responses were sustained at week 48. At least one asthma exacerbation (asthma worsening) was reported for 87 (32.3\%) patients receiving tiotropium $5 \mu \mathrm{g}, 97(37.3 \%)$ patients receiving tiotropium $2.5 \mu \mathrm{g}$, and $103(38.3 \%)$ patients receiving placebo during the 48-week treatment period. The ACQ-7 responder rates at week 24 were higher in the tiotropium groups than in the placebo group (tiotropium $5 \mu \mathrm{g}, 81.0 \%$; tiotropium $2.5 \mu \mathrm{g}$, 78.1\%; placebo, $70.3 \%$ ) (Table 3) [41].

The safety and tolerability of tiotropium were also examined in the pooled population of adolescents and children with symptomatic moderate asthma, with an overall mean exposure of $330.6 \pm 40.6$ days to the study drug, with the majority of patients receiving at least 280 days of treatment. Adverse events were reported by $61.7,63.5$, and $63.6 \%$ of patients receiving tiotropium 5 , $2.5 \mu \mathrm{g}$, and placebo, respectively. The proportion of patients with drug-related AEs was low $(1.5,0.4$, and $1.1 \%$, respectively). There were no AEs leading to discontinuation in the tiotropium groups and no deaths occurred. The most commonly reported AEs were asthma worsening, decreased PEF, and nasopharyngitis, of which asthma worsening was reported by more patients in the placebo group compared with tiotropium 5 and $2.5 \mu \mathrm{g}$ (33.1, 25.7, and $29.2 \%$ of patients, respectively) (Table 4). Overall, similar to findings in adults, results from the pooled analysis demonstrate that the safety and tolerability of oncedaily tiotropium as add-on to maintenance therapy were comparable to placebo [42].

\subsubsection{Symptomatic Severe Asthma}

In PensieTinA-asthma ${ }^{\circledR}$, adolescent patients were randomized to receive tiotropium 5 or $2.5 \mu \mathrm{g}$, or placebo over 12 weeks as either add-on to high-dose ICS $(>400 \mu \mathrm{g}$ of budesonide or equivalent in patients aged 12-14 years; 800-1600 $\mu \mathrm{g}$ in patients aged 15-17 years) plus one or more controllers (e.g., LABA and/or LTRA), or as add-on to medium-dose ICS (200-400 $\mu \mathrm{g}$ of budesonide or equivalent in patients aged 12-14 years; 400-800 $\mu \mathrm{g}$ in patients aged 15-17 years) plus two or more controllers (e.g., LABA, LTRA, or sustained-release theophylline) (Table 2) [34]. In this study, tiotropium $5 \mu \mathrm{g}$ provided numerical improvements in peak $\mathrm{FEV}_{1(0-3 \mathrm{~h})}$ compared with placebo [90 $\mathrm{mL}(95 \% \mathrm{CI}-19$ to $198 ; p=0.104)]$. There was a statistically significant improvement in peak $\mathrm{FEV}_{1(0-3 \mathrm{~h})}$ response with the $2.5-\mu \mathrm{g}$ dose $[111 \mathrm{~mL}$ (95\% CI $2-220 ; p=0.046)]$, but because the efficacy of tiotropium $5 \mu \mathrm{g}$ over placebo could not be demonstrated, and thus the primary endpoint of the trial was not met, all further treatment comparisons were considered descriptive only, to control the type I error [34]. Numerical improvements in trough $\mathrm{FEV}_{1}$ response at week 12 were observed with both tiotropium $5 \mu \mathrm{g}$ [54 mL (95\% CI -61 to $168 ; p=0.361)$ ] and tiotropium $2.5 \mu \mathrm{g} \quad[115 \mathrm{~mL} \quad(95 \%$ CI $\quad 0-231$; $p=0.051)]$ compared with placebo. The lack of statistical significance observed with these data was somewhat unexpected in view of all other investigations of tiotropium as add-on to at least ICS therapy in adolescents [33] and adults [27, 29] with asthma, which have demonstrated that the $5-\mu \mathrm{g}$ dose provides statistically significant improvements in both peak and trough $\mathrm{FEV}_{1}$.

With no minimal clinically important difference in lung function improvements established in pediatric patients, it is difficult to interpret the clinical relevance of non-significant changes. However, lung function improvements are broadly of the same magnitude in adolescents and children as previously reported in adults. The incidence of both severe exacerbations and episodes of asthma worsening were low, and the safety and tolerability of tiotropium were comparable to placebo. One patient in each 
Table 3 Key efficacy findings from pooled phase III studies with tiotropium Respimat ${ }^{\circledR} 5 \mu \mathrm{g}$ in adolescents and children with asthma

\begin{tabular}{|c|c|c|c|}
\hline Studies included in pooled analysis & $N$ & Primary and key secondary endpoints & $\begin{array}{l}\text { Difference from placebo, } \mathrm{mL} \\
(95 \% \mathrm{CI}) \\
p \text { value }\end{array}$ \\
\hline \multicolumn{4}{|l|}{ Symptomatic moderate asthma [41] } \\
\hline \multirow[t]{2}{*}{$\begin{array}{l}\text { RubaTinA-asthma }{ }^{\circledR} \\
\text { CanoTinA-asthma }{ }^{\circledR}\end{array}$} & \multirow[t]{2}{*}{269} & Peak FEV 1 & $\begin{array}{l}168 \\
(109-228) \\
<0.0001\end{array}$ \\
\hline & & Trough $\mathrm{FEV}_{1}$ & $\begin{array}{l}118 \\
(53-182) \\
0.0004\end{array}$ \\
\hline \multicolumn{4}{|l|}{ Symptomatic severe asthma [43] } \\
\hline \multirow[t]{3}{*}{$\begin{array}{l}\text { VivaTinA-asthma }{ }^{\circledR} \\
\text { PensieTinA-asthma }\end{array}$} & \multirow[t]{3}{*}{258} & Peak FEV 1 & $\begin{array}{l}117 \\
(51-183) \\
0.0005\end{array}$ \\
\hline & & Trough $\mathrm{FEV}_{1}$ & $\begin{array}{l}71 \\
(3-139) \\
0.04\end{array}$ \\
\hline & & $\operatorname{FEF}_{(25-75 \%)}$ & $\begin{array}{l}296 \\
(168-425) \\
<0.0001\end{array}$ \\
\hline
\end{tabular}

$C I$ confidence interval, $F E F_{(25-75 \%)}$ forced expiratory flow $25-75 \%, F E V_{l}$ forced expiratory volume in $1 \mathrm{~s}$

of the tiotropium 2.5- $\mu \mathrm{g}$ and placebo treatment groups and two patients receiving tiotropium $5 \mu \mathrm{g}$ experienced a severe asthma exacerbation during the study. At least one episode of asthma worsening was reported for 15 (11.5\%), $18(14.2 \%)$, and $25(18.5 \%)$ patients receiving tiotropium 5, $2.5 \mu \mathrm{g}$, and placebo, respectively. The ACQ-7 scores at week 12 were comparable for both tiotropium doses and were not significantly different to findings with placebo.

The VivaTinA-asthma ${ }^{\circledR}$ study was the first phase III study of tiotropium in children (aged 6-11 years) with symptomatic severe disease. Over a 12 -week period, the efficacy and safety of tiotropium added on to high-dose ICS ( $>400 \mu \mathrm{g} /$ day) with one or more controller medication or medium-dose ICS (200-400 $\mu \mathrm{g} /$ day) with two or more controller medications in symptomatic severe asthma were assessed [36]. Compared with placebo, tiotropium $5 \mu \mathrm{g}$ add-on therapy significantly improved the primary endpoint, peak $\mathrm{FEV}_{1(0-3 \mathrm{~h})} \quad[139 \mathrm{~mL} \quad(95 \%$ CI $75-203$; $p<0.001)$. Similarly, a significant difference was observed in improvements in trough $\mathrm{FEV}_{1}$ response vs. placebo for the 5 - $\mu \mathrm{g}$ dose. No significant differences in adjusted mean peak forced vital capacity (FVC) within $3 \mathrm{~h}$ post-dose $\left[\mathrm{FVC}_{(0-3 \mathrm{~h})}\right]$ or trough $\mathrm{FVC}$ responses were observed with either dose of tiotropium.

The safety and tolerability of tiotropium were comparable to placebo. A severe exacerbation was experienced by seven $(5.4 \%)$, three $(2.2 \%)$, and eight $(6.0 \%)$ participants being treated with tiotropium $5,2.5 \mu \mathrm{g}$, or placebo, respectively. At least one episode of asthma worsening was reported for $26.9,21.3$, and $35.1 \%$ of those receiving tiotropium $5,2.5 \mu \mathrm{g}$, or placebo, respectively. The risk of severe asthma exacerbations and episodes of asthma worsening was lower with tiotropium than with placebo, a difference that reached statistical significance for episodes of asthma worsening with tiotropium $2.5 \mu \mathrm{g}$ vs. placebo $(p=0.006)$. Changes in ACQ-IA scores were similar between tiotropium and placebo, with over $75 \%$ of participants in each group showing a response (improvement of at least 0.5 ). In addition, there was no difference in improvement in the adjusted mean number of asthma symptom-free days with both doses of tiotropium compared with placebo. Once-daily tiotropium was also well tolerated as an add-on therapy to ICS with other maintenance therapies in children with symptomatic severe asthma [36].

In the pooled analysis of these data, it was shown that in patients aged 6-17 years with symptomatic severe asthma $(n=792)$, either dose of tiotropium added on to ICS significantly improved measures of lung function (Table 3) [43]. Peak $\mathrm{FEV}_{1(0-3 \mathrm{~h})}$ response at week 12 was significantly improved with both the 5 and $2.5-\mu \mathrm{g}$ dose of tiotropium vs. placebo; the adjusted difference vs. placebo was $117 \mathrm{~mL}$ (95\% CI 51-183; $p=0.0005)$ and $74 \mathrm{~mL}$ (95\% CI 8-140; $p=0.027$, respectively. Improvements in forced 
Table 4 Summary of safety outcomes from a pooled analysis of adolescents and children with symptomatic moderate asthma [42]

\begin{tabular}{|c|c|c|c|}
\hline & $\begin{array}{l}\text { Tiotropium Respimat }{ }^{\circledR} 5 \mu \mathrm{g} \\
(n=269)\end{array}$ & $\begin{array}{l}\text { Tiotropium Respimat }{ }^{\circledR} 2.5 \mu \mathrm{g} \\
(n=260)\end{array}$ & $\begin{array}{l}\text { Placebo } \\
\text { Respimat }^{\circledR} \\
(n=269)\end{array}$ \\
\hline Patients with any $\mathrm{AE}, n(\%)$ & $166(61.7)$ & $165(63.5)$ & $171(63.6)$ \\
\hline Patients with drug-related $\mathrm{AEs}^{\mathrm{a}}, n(\%)$ & $4(1.5)$ & $1(0.4)$ & $3(1.1)$ \\
\hline Patients with AEs leading to discontinuation, $n(\%)$ & 0 & 0 & $2(0.7)$ \\
\hline Patients with serious AEs, $n(\%)$ & $4(1.5)$ & $5(1.9)$ & $8(3.0)$ \\
\hline \multicolumn{4}{|c|}{ AEs in $\geq 2 \%$ of patients in any treatment arm, by preferred term } \\
\hline Asthma worsening & $69(25.7)$ & $76(29.2)$ & $89(33.1)$ \\
\hline Decreased PEF rate & $35(13.0)$ & $40(15.4)$ & $35(13.0)$ \\
\hline Nasopharyngitis & $31(11.5)$ & $28(10.8)$ & $30(11.2)$ \\
\hline Respiratory tract infection viral & $18(6.7)$ & $19(7.3)$ & $19(7.1)$ \\
\hline Respiratory tract infection & $15(5.6)$ & $16(6.2)$ & $21(7.8)$ \\
\hline Upper respiratory tract infection & $13(4.8)$ & $5(1.9)$ & $10(3.7)$ \\
\hline Headache & $11(4.1)$ & $12(4.6)$ & $4(1.5)$ \\
\hline Rhinitis allergic & $9(3.3)$ & $7(2.7)$ & $11(4.1)$ \\
\hline Viral infection & $9(3.3)$ & $7(2.7)$ & $6(2.2)$ \\
\hline Rhinitis & $8(3.0)$ & $11(4.2)$ & $10(3.7)$ \\
\hline Pharyngitis & $6(2.2)$ & $9(3.5)$ & $9(3.3)$ \\
\hline Bronchitis & $5(1.9)$ & $9(3.5)$ & $3(1.1)$ \\
\hline Tonsillitis & $4(1.5)$ & $6(2.3)$ & $10(3.7)$ \\
\hline Sinusitis & $4(1.5)$ & $7(2.7)$ & $3(1.1)$ \\
\hline Cough & $2(0.7)$ & $6(2.3)$ & $5(1.9)$ \\
\hline
\end{tabular}

Findings from a pooled analysis of the RubaTinA-asthma ${ }^{\circledR}$ and CanoTinA-asthma ${ }^{\circledR}$ studies

$A E$ adverse event, $P E F$ peak expiratory flow

${ }^{a}$ Investigator-defined

expiratory flow between 25 and $75 \%$ of vital capacity response, more closely representing changes in the lower airways, and the $\mathrm{FEV}_{1} / \mathrm{FVC}$ ratio, as the pivotal marker of obstructive lung disease, were also reported. Only the 5- $\mu \mathrm{g}$ dose of tiotropium significantly improved trough $\mathrm{FEV}_{1}$ compared with placebo [43]. While findings from the pooled analysis demonstrate significant improvements in peak $\mathrm{FEV}_{1(0-3 \mathrm{~h})}$ response compared with placebo, it must be acknowledged that this primary endpoint was not met in PensieTinA-asthma ${ }^{\circledR}$, which was conducted solely in adolescents.

As discussed later, studies in children and adolescents present challenges; poor adherence, a common problem in asthma management, may in part explain these findings, in addition to the short study duration (12 weeks) and the strong placebo effect observed, pointing towards a possible low treatment adherence prior to inclusion [34]. While the pooled analysis involves a large number of patients across a wide age range, the limitations of these types of analyses must also be acknowledged. Regarding safety, the most common AEs, with an incidence $>2 \%$ in any treatment group in either study, were asthma, decreased PEF rate, and nasopharyngitis (Table 5) [43]. Overall, this pooled analysis confirms that the addition of tiotropium to existing controller medication improves lung function in children and adolescents with symptomatic severe asthma.

Observations of improvements in lung function with tiotropium add-on therapy in children and adolescents with symptomatic moderate or severe asthma are consistent with findings in adults with symptomatic asthma [26, 27, 29]. However, the dose response observed in children and adolescents with symptomatic moderate asthma was not observed to the same extent in patients with severe disease [34]. Furthermore, improvements in asthma control were observed across age groups and asthma severities in all treatment groups, including placebo. However, the studies were not statistically powered to assess asthma symptom scores. It must be acknowledged that short study durations in children and adolescents with symptomatic severe asthma do not allow for a comprehensive assessment of asthma control and exacerbations. In all the studies reported here, the frequency of severe exacerbations in children and adolescents were low and did not allow for the calculation of any treatment effect. The published 
Table 5 Summary of safety outcomes from a pooled analysis of adolescents and children with symptomatic severe asthma [43]

\begin{tabular}{llll}
\hline & $\begin{array}{l}\text { Tiotropium Respimat }^{\circledR} 5 \mu \mathrm{g} \\
(n=260)\end{array}$ & $\begin{array}{l}\text { Tiotropium Respimat }^{\circledR} \text { 2.5 } \text { Rg }^{(n=263)} \\
\text { Placebo Respimat } \\
(n=269)\end{array}$ & $114(42.4)$ \\
\hline Patients with any AE, $n(\%)$ & $99(38.1)$ & $101(38.4)$ & $3(1.1)$ \\
Patients with drug-related AEs ${ }^{\mathrm{a}}, n(\%)$ & $1(0.4)$ & 0 & $3(1.1)$ \\
Patients with AEs leading to discontinuation, $n(\%)$ & $2(0.8)$ & 0 & $2(0.7)$ \\
Patients with serious AEs, $n(\%)$ & $6(2.3)$ & $3(1.1)$ & $44(16.4)$ \\
AEs in $>2 \%$ of patients in any treatment arm, by preferred term & $39(15.0)$ & $34(12.9)$ & $33(12.3)$ \\
Asthma & $20(7.7)$ & $24(9.1)$ & $14(5.2)$ \\
Decreased PEF rate & $11(4.2)$ & $11(4.2)$ & $7(2.6)$ \\
Nasopharyngitis & $6(2.3)$ & $2(0.8)$ & $7(2.6)$ \\
Viral respiratory tract infection viral & $4(1.5)$ & $1(0.4)$ & $8(3.0)$ \\
Respiratory tract infection & $2(0.8)$ & $3(1.1)$ & $4(1.5)$ \\
Rhinitis & $4(1.5)$ & $3(1.1)$ & \\
Upper respiratory tract infection & & \\
\hline
\end{tabular}

Findings from a pooled analysis of the PensieTinA-asthma ${ }^{\circledR}$ and VivaTinA-asthma ${ }^{\circledR}$ studies

$A E$ adverse event, $P E F$ peak expiratory flow

${ }^{\mathrm{a}}$ Investigator-defined

evidence, however, demonstrates that tiotropium is a safe and well-tolerated treatment.

In addition to the studies reported here, a further analysis of the safety and tolerability of once-daily tiotropium add-on therapy was assessed in a pooled analysis using data from $>1600$ patients aged 1-17 years with symptomatic asthma of different severities. Safety findings were comparable to placebo regardless of age group and asthma severity. This finding is of particular importance for children, where safety is the major consideration prior to the incorporation of new treatment strategies [44].

\section{Perspectives for Future Research}

Further research is required to help determine the optimal position for tiotropium in asthma management guidelines for children and adolescents. Several questions remain unanswered in this context, including non-compliance, which presents a major challenge, especially in older children [45]. An effective bronchodilator with a oncedaily regimen might increase the chance of sustained asthma control, especially in addition to once-daily ICS or ICS/LABA treatment $[33,34,46]$. To date, there is no published evidence on the effect of tiotropium on nighttime awakening in children and adolescents. Children with poorly controlled asthma are at risk of sleep interference and night-time awakenings, potentially leading to loss of concentration or absence from school [3, 47-49]. Future studies are required to evaluate this, and evidence will provide a better understanding of the position of tiotropium in asthma management guidelines. There is currently only one ongoing study with tiotropium in children (NCT03199976). This open-label study evaluates the effect of intermittent tiotropium bromide and salbutamol as needed vs. intermittent fluticasone propionate and salbutamol as needed, or solely, salbutamol as needed on episode-free days in infants and toddlers with recurrent episodes of wheeze and/or shortness of breath. Results from this study, as well as the recently completed NinoTinA-asthma study (NCT01634113) [37], may shed light on the effect of tiotropium in very young children with asthma-like symptoms or wheezy bronchitis.

Identifying or assessing whether certain populations of adolescents and children with asthma are responders to tiotropium is also an important aspect for consideration in future research. Evidence with tiotropium has shown it to be a well-tolerated treatment that improves lung function and asthma control in all patient phenotypes and asthma severities studied. Furthermore, a study in adults has reported that tiotropium $5 \mu \mathrm{g}$ improved lung function, reduced the risk of exacerbations (time to first severe exacerbation), and improved asthma symptom control independent of immunoglobulin E levels, eosinophil counts, age, sex, or baseline demographics compared with placebo [50]. Preliminary data from a pooled analysis of trials in children and adolescents confirmed the notion that tiotropium is effective in improving lung function independent from allergic status (immunoglobulin E serum levels) or eosinophil blood counts [51]. Thus, the evidence suggests tiotropium is a convenient option for incorporation into patient care, with no need for patient phenotyping. 
However, this finding needs to be confirmed in adolescents and children. The improvements in lung function observed in children with once-daily tiotropium add-on therapy compared with placebo are shown to be irrespective of the degree of airflow obstruction at baseline [52]. Previously, greater bronchodilator responsiveness to SABAs was reported as a predictor of a positive clinical response to tiotropium in adults with asthma [53]. Considering the mode of action of tiotropium, this is not completely unexpected, but findings need to be confirmed in children and adolescents. This would allow an inexpensive and simple test to be performed prior to adding tiotropium to ICS or for switching to tiotropium from another second controller.

It is well acknowledged that some patients still have symptomatic disease despite the use of currently available therapies [54] and some patients may not respond well to certain therapies [53]. The efficacy of tiotropium both added on to medium- and low-dose ICS has been demonstrated in adults [26, 27]. To date, no study has directly compared the efficacy of tiotropium with that of LABAs as an add-on to ICS in adolescents and children. Availability of this evidence would help to enhance understanding of the evolving role of tiotropium in clinical practice and better integrate this therapy into current guidelines.

Chronic inflammation in asthma impacts airway remodeling, and involves changes such as goblet cell metaplasia, airway smooth muscle thickening, and extracellular matrix deposition [19], which ultimately manifest as disease persistence and progression. Acetylcholine is thought to induce proinflammatory responses of both inflammatory and structural cells in the airways, in addition to profibrotic effects via muscarinic receptor stimulation on mesenchymal, epithelial, and inflammatory cells [19]. As discussed earlier, anticholinergic agents can reduce the acetylcholineinduced inflammatory response and may have an inhibitory effect on airway remodeling $[19,20]$. Thus, it is likely that the impact of LAMAs extends beyond that of bronchodilators to potentially enhance the anti-inflammatory and bronchodilator effects of LABAs. Further studies are recommended in this area to confirm the potential impact of tiotropium on airway inflammation and remodeling.

Exacerbations and disease progression are a major concern in children with asthma. Evidence suggests that children with reduced growth of lung function are at an increased risk of fixed airflow obstruction and hence exacerbations [55]. An analysis from the Childhood Asthma Management Program suggested that lower pulmonary function predicts increased exacerbations [56, 57], and in a study from the Inner-City Asthma Consortium, a recent exacerbation, together with impaired lung function, emerged as important predictors of an increased risk of exacerbations in this population group [58]. However, it is unknown whether the exacerbations are a result of the low pulmonary function or if multiple exacerbations result in reduced pulmonary function owing to irreversible losses in lung function. Longer-term studies in patients at risk of disease progression or frequent exacerbations are needed to provide such insights. Based on these observations, it should be considered whether bronchodilators or their bronchoprotective properties prevent asthma exacerbations and thus ongoing irrecoverable loss in lung function. While there is a trend for tiotropium to reduce exacerbations, a study that focuses on patients at risk of exacerbations is needed to confirm that finding.

\section{Challenges of Asthma Management in Adolescents and Children}

Education and support are recognized as important components of care in all patients with asthma, regardless of age [4]. Challenges in the treatment of patients with asthma include topics such as adherence, awareness of the importance of disease management, self-monitoring and potential underestimation of symptoms, declining and irreversible lung function, exacerbations in otherwise controlled patients, and the risk of frequent exacerbations in partly controlled patients $[4,59,60]$. GINA recommends a continuous cycle of assessment, treatment, and review. As part of this, physicians should aim to recognize patients who may be adapting to their symptoms, e.g., children with poorly controlled asthma avoiding physical exercise, thus reporting that their disease is well controlled [4]. It is important for the healthcare professional to regularly review treatment choice and device handling, and to be aware of the gap between patient perception and the clinical definition of asthma treatment and control, so that clinic visits can be tailored accordingly [59]. It has been suggested that using a motivational interview technique, a patient-centered communication skills approach, to help establish a collaborative relationship may be helpful in clinical practice [61]. Empowering adolescents and young adults to play an active role in their own care means they may be more receptive to advice, and research suggests they are more likely to be receptive to change when they independently set goals for themselves [61].

Essential components of guided asthma management include self-monitoring of symptoms and peak flow, a written asthma action plan to recognize and respond to worsening asthma, and regular review of asthma control in partnership with a healthcare professional [62]. The provision of information and education to support asthma management should be considered an evolving process, with previous details being reinforced at each opportunity. Furthermore, education and support can be delivered at several 
points of care by the multidisciplinary team, including pharmacists, nurses, and community health workers, in addition to the primary care professional $[63,64]$.

Poor medication adherence is a common occurrence in children and adolescents with asthma, and can result in suboptimal asthma control [65, 66], which may in part explain the placebo effect observed in the PensieTinAasthma ${ }^{\circledR}$ trial [34]. A recent analysis of posts from an online forum for patients with asthma established poor inhaler technique, inhaler characteristics, choosing a device, and the embarrassment of using the inhaler because of asthma stigma as some of the factors that can impact treatment adherence in adolescents [67]. The availability of once-daily dosing with tiotropium may therefore be particularly helpful in the younger patient group. Furthermore, the Respimat ${ }^{\circledR}$ Soft Mist ${ }^{\mathrm{TM}}$ Inhaler, which can be used with a spacer if necessary, is easy to inhale [68] and delivers a dose independent of a patient's variable inspiratory flow, facilitating efficient lung deposition $[69,70]$, which should especially benefit younger patients with asthma. Evidence also suggests a drive toward the use of new strategies, such as electronic monitoring device technology, to help with the challenges of poor adherence [67, 71]. However, effective and repeated instruction on inhaler technique remains of considerable importance, particularly in younger patients [4].

In younger children, education is primarily targeted at the parent/caretaker; however, patients should also be taught simple asthma management skills from a young age as building blocks for expanding knowledge with age. In adolescents, healthcare professionals should be particularly aware of psychological challenges such as anxiety and poor self-esteem [60]. Enabling adolescents to understand their disease (including its potential long-term nature) and the importance of adhering to treatment are significant aspects of care. Social and psychological support may be required to help initiate and maintain positive behavioral change, such as involving adolescents in a forum where they feel comfortable discussing their personal experiences with asthma and how they manage their disease [60]. Peer support groups may provide additional support to any details provided by the primary care professional, and given the widespread use of technology and social media among the adolescent population, there may be opportunities to access supportive patient websites, apps, and online forums to help reduce potential isolation [60, 71]. GINA also provides patient educational materials and links to asthma websites [4].

\section{Conclusion}

Findings from pooled analyses of phase III clinical trials in adolescents and children have shown improved lung function and asthma control where tiotropium Respimat ${ }^{\circledR}$ is used as add-on therapy to ICS with or without other controllers in patients with poorly controlled asthma. These findings were reported in adolescents and children with symptomatic moderate or severe asthma, and are consistent with previous data from trials of tiotropium in adult patients with comparable disease severities. This makes tiotropium a useful and novel add-on treatment option, especially in patients where standard therapy with moderate-to-high ICS with or without a LABA does not result in sufficient asthma control. Understanding the challenges faced by adolescents and children with asthma, and implementing tailored communication strategies to help optimize disease management in this population, is an important component of clinical care.

Author Contributions The authors take full responsibility for the scope, direction, content of, and editorial decisions relating to the manuscript, were involved at all stages of development, and have approved the submitted manuscript.

\section{Compliance with Ethical Standards}

Funding Medical writing assistance, in the form of the preparation and revision of the draft manuscript, was supported financially by Boehringer Ingelheim and provided by Louise Brady, PhD, of MediTech Media under the authors' conceptual direction and based on feedback from the authors. Boehringer Ingelheim was given the opportunity to review the manuscript for factual accuracy only.

Conflict of interest Eckard Hamelmann has served on scientific advisory boards and received honorarium for lectures on scientific meetings from ALK, Allergopharma, Bencard, Boehringer Ingelheim, LETI Pharma, Novartis, Nutricia, and Stallergenes. Stanley J. Szefler has consulted for Aerocrine, AstraZeneca, Boehringer Ingelheim, Daiichi Sankyo, GlaxoSmithKline, Genentech, Merck, Novartis, Roche, and Teva, and has received research support from the National Institutes of Health, the National Heart, Lung and Blood Institute, the National Institute for Allergy and Infectious Diseases, the National Institute of Environmental and Health Sciences, the Environmental Protection Agency, the Colorado Cancer, Cardiovascular and Pulmonary Disease Program, and GlaxoSmithKline.

Open Access This article is distributed under the terms of the Creative Commons Attribution-NonCommercial 4.0 International License (http://creativecommons.org/licenses/by-nc/4.0/), which permits any noncommercial use, distribution, and reproduction in any medium, provided you give appropriate credit to the original author(s) and the source, provide a link to the Creative Commons license, and indicate if changes were made.

\section{References}

1. World Health Organization. Asthma. Fact sheet 307. Updated 2017. http://www.who.int/mediacentre/factsheets/fs307/en/. Accessed 1 Jul 2017.

2. Asthma UK. Asthma facts and FAQs. http://www.asthma.org.uk/ about/media/facts-and-statistics/. Accessed 14 Nov 2017.

3. Schmier JK, Manjunath R, Halpern MT, Jones ML, Thompson K, Diette GB. The impact of inadequately controlled asthma in 
urban children on quality of life and productivity. Ann Allergy Asthma Immunol. 2007;98:245-51.

4. Global Initiative for Asthma. Global strategy for asthma management and prevention. http://ginasthma.org/gina-reports/. Accessed 9 Mar 2017.

5. Custovic A, Johnston SL, Pavord I, Gaga M, Fabbri L, Bel EH, et al. EAACI position statement on asthma exacerbations and severe asthma. Allergy. 2013;68:1520-31.

6. Belgrave DC, Buchan I, Bishop C, Lowe L, Simpson A, Custovic A. Trajectories of lung function during childhood. Am J Respir Crit Care Med. 2014;189:1101-9.

7. Rodrigo GJ, Neffen H. A systematic review of the efficacy and safety of a fixed-dose combination of umeclidinium and vilanterol for the treatment of COPD. Chest. 2015;148:397-407.

8. Cazzola M, Ora J, Rogliani P, Matera MG. Role of muscarinic antagonists in asthma therapy. Expert Rev Respir Med. 2017;11:239-53.

9. Griffiths B, Ducharme FM. Combined inhaled anticholinergics and short-acting beta2-agonists for initial treatment of acute asthma in children. Cochrane Database Syst Rev. 2013;(8):CD000060.

10. Rodrigo GJ, Castro-Rodriguez JA. Anticholinergics in the treatment of children and adults with acute asthma: a systematic review with meta-analysis. Thorax. 2005;60:740-6.

11. Canning BJ. Reflex regulation of airway smooth muscle tone. J Appl Physiol (1985). 2006;101:971-85.

12. Vogelberg C. Emerging role of long-acting anticholinergics in children with asthma. Curr Opin Pulm Med. 2016;22:74-9.

13. Hashimoto A, Maeda H, Yokoyama M. Augmentation of parasympathetic nerve function in patients with extrinsic bronchial asthma: evaluation by coefficiency of variance of R-R interval with modified long-term ECG monitoring system. Kobe J Med Sci. 1996;42:347-59.

14. Novelli F, Malagrino L, Dente FL, Paggiaro P. Efficacy of anticholinergic drugs in asthma. Expert Rev Respir Med. 2012;6:309-19.

15. Gosens R, Zaagsma J, Meurs H, Halayko AJ. Muscarinic receptor signaling in the pathophysiology of asthma and COPD. Respir Res. 2006;7:73.

16. Barnes PJ. The pharmacological properties of tiotropium. Chest. 2000;117(Suppl. 2):63S-6S.

17. Disse B, Speck GA, Rominger KL, Witek TJ Jr, Hammer R. Tiotropium (Spiriva): mechanistical considerations and clinical profile in obstructive lung disease. Life Sci. 1999;64:457-64.

18. Haddad EB, Mak JC, Barnes PJ. Characterization of [3H]Ba 679 $\mathrm{BR}$, a slowly dissociating muscarinic antagonist, in human lung: radioligand binding and autoradiographic mapping. Mol Pharmacol. 1994;45:899-907.

19. Meurs H, Oenema TA, Kistemaker LE, Gosens R. A new perspective on muscarinic receptor antagonism in obstructive airways diseases. Curr Opin Pharmacol. 2013;13:316-23.

20. Radovanovic D, Santus P, Blasi F, Mantero M. The evidence on tiotropium bromide in asthma: from the rationale to the bedside. Multidiscip Respir Med. 2017;12:17.

21. Halpin DM, Kaplan AG, Russell RK. Why choose tiotropium for my patient? A comprehensive review of actions and outcomes versus other bronchodilators. Respir Med. 2017;128:28-41.

22. Bos IS, Gosens R, Zuidhof AB, Schaafsma D, Halayko AJ, Meurs $\mathrm{H}$, et al. Inhibition of allergen-induced airway remodelling by tiotropium and budesonide: a comparison. Eur Respir J. 2007;30:653-61.

23. Ohta S, Oda N, Yokoe T, Tanaka A, Yamamoto Y, Watanabe Y, et al. Effect of tiotropium bromide on airway inflammation and remodelling in a mouse model of asthma. Clin Exp Allergy. 2010;40:1266-75.
24. Halpin DM. Tiotropium in asthma: what is the evidence and how does it fit in? World Allergy Organ J. 2016;9:29.

25. Novelli F, Costa F, Latorre M, Malagrino L, Celi A, Vagaggini B, et al. Tiotropium: a new therapeutic option in asthma. Monaldi Arch Chest Dis. 2013;79:109-15.

26. Paggiaro P, Halpin DM, Buhl R, Engel M, Zubek VB, Blahova Z, et al. The effect of tiotropium in symptomatic asthma despite low- to medium-dose inhaled corticosteroids: a randomized controlled trial. J Allergy Clin Immunol Pract. 2016;4:104-13.

27. Kerstjens HA, Casale TB, Bleecker ER, Meltzer EO, Pizzichini E, Schmidt O, et al. Tiotropium or salmeterol as add-on therapy to inhaled corticosteroids for patients with moderate symptomatic asthma: two replicate, double-blind, placebo-controlled, parallelgroup, active-comparator, randomised trials. Lancet Respir Med. 2015;3:367-76.

28. Ohta K, Ichinose M, Tohda Y, Engel M, Moroni-Zentgraf P, Kunimitsu S, et al. Long-term once-daily tiotropium Respimat ${ }^{\circledR}$ is well tolerated and maintains efficacy over 52 weeks in patients with symptomatic asthma in Japan: a randomised, placebo-controlled study. PLoS One. 2015;10:e0124109.

29. Kerstjens HA, Engel M, Dahl R, Paggiaro P, Beck E, Vandewalker $\mathrm{M}$, et al. Tiotropium in asthma poorly controlled with standard combination therapy. $\mathrm{N}$ Engl J Med. 2012;367:1198-207.

30. Dahl R, Engel M, Dusser D, Halpin D, Kerstjens HA, ZarembaPechmann L, et al. Safety and tolerability of once-daily tiotropium Respimat ${ }^{\circledR}$ as add-on to at least inhaled corticosteroids in adult patients with symptomatic asthma: a pooled safety analysis. Respir Med. 2016;118:102-11.

31. Vogelberg C, Engel M, Moroni-Zentgraf P, Leonaviciute-Klimantaviciene $M$, Sigmund R, Downie J, et al. Tiotropium in asthmatic adolescents symptomatic despite inhaled corticosteroids: a randomised dose-ranging study. Respir Med. 2014;108:1268-76.

32. Vogelberg C, Moroni-Zentgraf P, Leonaviciute-Klimantaviciene M, Sigmund R, Hamelmann E, Engel M, et al. A randomised dose-ranging study of tiotropium Respimat $^{{ }^{\circledR}}$ in children with symptomatic asthma despite inhaled corticosteroids. Respir Res. 2015;16:20.

33. Hamelmann E, Bateman ED, Vogelberg C, Szefler SJ, Vandewalker M, Moroni-Zentgraf $\mathrm{P}$, et al. Tiotropium add-on therapy in adolescents with moderate asthma: a 1-year randomized controlled trial. J Allergy Clin Immunol. 2016;138:441-50.

34. Hamelmann E, Bernstein JA, Vandewalker M, Moroni-Zentgraf P, Verri D, Unseld A, et al. A randomised controlled trial of tiotropium in adolescents with severe symptomatic asthma. Eur Respir J. 2017;49(1):1601100.

35. Schmidt O, Hamelmann E, Vogelberg C, Laki I, El Azzi G, Engel $\mathrm{M}$, et al. Once-daily tiotropium Respimat ${ }^{\circledR}$ add-on therapy improves lung function in children with moderate symptomatic asthma. Eur Respir J. 2016;48 (Suppl. 60):PA4398.

36. Szefler SJ, Murphy K, Harper T, Boner A, Laki I, Engel M, et al. A phase III randomized controlled trial of tiotropium add-on therapy in children with severe symptomatic asthma. J Allergy Clin Immunol. 2017;140:1277-87.

37. Vrijlandt E, El Azzi G, El Azzi G, Vandewalker M, Rupp N, Harper T, et al. Safety and efficacy of tiotropium in 1-5-year-old children with persistent asthmatic symptoms: a randomised, double-blind, placebo-controlled trial. Lancet Respir Med. 2018. (in press).

38. Rodrigo GJ, Neffen H. Efficacy and safety of tiotropium in school-age children with moderate to severe symptomatic asthma: a systematic review. Pediatr Allergy Immunol. 2017;26:551-6.

39. Rodrigo GJ, Castro-Rodriguez JA. Tiotropium for the treatment of adolescents with moderate to severe symptomatic asthma: a 
systematic review with meta-analysis. Ann Allergy Asthma Immunol. 2015;115:211-6.

40. Vogelberg C, Laki I, Schmidt O, Hamelmann E, El Azzi G, Engel $\mathrm{M}$, et al. Safety and tolerability of once-daily tiotropium Respimat ${ }^{\circledR}$ add-on therapy in children with moderate symptomatic asthma. Eur Respir J. 2016;48 (Suppl. 60):PA4399.

41. Vogelberg C, Hamelmann E, Szefler S, El Azzi G, MoroniZentgraf P, Engel M, et al. Once-daily tiotropium Respimat addon therapy improves lung function and control in adolescents and children with moderate symptomatic asthma. J Allergy Clin Immunol. 2017;139(2):AB95.

42. Vandewalker M, Hamelmann E, Engel M, El Azzi G, MoroniZentgraf P, Unseld A, et al. Once daily tiotropium Respimat addon therapy has a safety profile comparable with placebo in children and adolescents. J Allergy Clin Immunol. 2017;139(2):AB94.

43. Hamelmann E, Vogelberg C, Goldstein S, El Azzi G, Engel M, Sigmund R, et al. Once-daily tiotropium Respimat add-on therapy improves lung function in patients aged 6-17 years with severe symptomatic asthma. Pediatr Pulmonol. 2017;52(S46):S100S176.

44. Vogelberg C, Hamelmann E, Vrijlandt E, Engel M, El Azzi G, Moroni-Zentgraf $\mathrm{P}$, et al. Tiotropium add-on therapy has a safety profile comparable with that of placebo in children and adolescents with symptomatic asthma. Allergy. 2017;72(S103):414.

45. Morton RW, Everard ML, Elphick HE. Adherence in childhood asthma: the elephant in the room. Arch Dis Child. 2014;99:949-53.

46. Boonsawat W, Goryachkina L, Jacques L, Frith L. Combined salmeterol/fluticasone propionate versus fluticasone propionate alone in mild asthma: a placebo-controlled comparison. Clin Drug Investig. 2008;28:101-11.

47. Diette GB, Markson L, Skinner EA, Nguyen TT, Algatt-Bergstrom P, Wu AW. Nocturnal asthma in children affects school attendance, school performance, and parents' work attendance. Arch Pediatr Adolesc Med. 2000;154:923-8.

48. Stores G, Ellis AJ, Wiggs L, Crawford C, Thomson A. Sleep and psychological disturbance in nocturnal asthma. Arch Dis Child. 1998;78:413-9.

49. Gustafsson D, Olofsson N, Andersson F, Lindberg B, Schollin J. Intervention models on psycho-social health in families with an asthmatic child. Pediatr Allergy Immunol. 2000;11:241-5.

50. Kerstjens HA, Moroni-Zentgraf P, Tashkin DP, Dahl R, Paggiaro $\mathrm{P}$, Vandewalker $\mathrm{M}$, et al. Tiotropium improves lung function, exacerbation rate, and asthma control, independent of baseline characteristics including age, degree of airway obstruction, and allergic status. Respir Med. 2016;117:198-206.

51. Hamelmann E, Vogelberg C, Voelker B, El Azzi G, Engel M, Sigmund R, Szefler SJ. Tiotropium add-on therapy improves lung function in children and adolescents with moderate and severe symptomatic asthma, independent of markers of allergic status. Allergy. 2017;72:S103.

52. Vogelberg C, Halpin D, Voelker B, Engel M, Luehmann, Hamelmann E. Once-daily tiotropium Respimat ${ }^{\circledR}$ add-on therapy improves lung function in children with moderate symptomatic asthma, independent of the degree of airflow obstruction. Eur Respir J. 2017;50:4040.

53. Peters SP, Bleecker ER, Kunselman SJ, Icitovic N, Moore WC, Pascual $\mathrm{R}$, et al. Predictors of response to tiotropium versus salmeterol in asthmatic adults. J Allergy Clin Immunol. 2013;132:1068-74.e1.

54. Bateman ED, Boushey HA, Bousquet J, Busse WW, Clark TJ, Pauwels RA, et al. Can guideline-defined asthma control be achieved? The Gaining Optimal Asthma ControL study. Am J Respir Crit Care Med. 2004;170:836-44.

55. McGeachie MJ, Yates KP, Zhou X, Guo F, Sternberg AL, Van Natta ML, et al. Patterns of growth and decline in lung function in persistent childhood asthma. N Engl J Med. 2016;374:1842-52.

56. Wu AC, Gregory M, Kymes S, Lambert D, Edler J, Stwalley D, et al. Modeling asthma exacerbations through lung function in children. J Allergy Clin Immunol. 2012;130:1065-70.

57. Fuhlbrigge AL, Kitch BT, Paltiel AD, Kuntz KM, Neumann PJ, Dockery DW, et al. FEV(1) is associated with risk of asthma attacks in a pediatric population. J Allergy Clin Immunol. 2001;107:61-7.

58. Teach SJ, Gergen PJ, Szefler SJ, Mitchell HE, Calatroni A, Wildfire J, et al. Seasonal risk factors for asthma exacerbations among inner-city children. J Allergy Clin Immunol. 2015;135:146-73.e5.

59. Yawn BP. The role of the primary care physician in helping adolescent and adult patients improve asthma control. Mayo Clin Proc. 2011;86:894-902.

60. de Benedictis D, Bush A. Asthma in adolescence: is there any news? Pediatr Pulmonol. 2017;52:129-38.

61. Schaefer MR, Kavookjian J. The impact of motivational interviewing on adherence and symptom severity in adolescents and young adults with chronic illness: a systematic review. Patient Educ Couns. 2017;100(12):2190-9.

62. Gibson PG, Powell H, Coughlan J, Wilson AJ, Abramson M, Haywood P, et al. Self-management education and regular practitioner review for adults with asthma. Cochrane Database Syst Rev. 2002;(1):CD001117.

63. Campbell JD, Brooks M, Hosokawa P, Robinson J, Song L, Krieger J. Community health worker home visits for Medicaidenrolled children with asthma: effects on asthma outcomes and costs. Am J Public Health. 2015;105:2366-72.

64. Partridge MR, Caress AL, Brown C, Hennings J, Luker K, Woodcock A, et al. Can lay people deliver asthma self-management education as effectively as primary care based practice nurses? Thorax. 2008;63:778-83.

65. Burgess S, Sly P, Devadason S. Adherence with preventive medication in childhood asthma. Pulm Med. 2011;2011:973849.

66. Navaratnam P, Friedman HS, Urdaneta E. The impact of adherence and disease control on resource use and charges in patients with mild asthma managed on inhaled corticosteroid agents. Patient Prefer Adherence. 2010;4:197-205.

67. De Simoni A, Horne R, Fleming L, Bush A, Griffiths C. What do adolescents with asthma really think about adherence to inhalers? Insights from a qualitative analysis of a UK online forum. BMJ Open. 2017;7:e015245.

68. Kamin W, Frank M, Kattenbeck S, Moroni-Zentgraf P, Wachtel $\mathrm{H}$, Zielen S. A handling study to assess use of the Respimat ${ }^{\circledR}$ Soft Mist $^{\mathrm{TM}}$ Inhaler in children under 5 years old. J Aerosol Med Pulm Drug Deliv. 2015;28:372-81.

69. Dalby R, Spallek M, Voshaar T. A review of the development of Respimat Soft Mist Inhaler. Int J Pharm. 2004;283:1-9.

70. Dalby RN, Eicher J, Zierenberg B. Development of Respimat ${ }^{\circledR}$ Soft Mist ${ }^{\mathrm{TM}}$ Inhaler and its clinical utility in respiratory disorders. Med Devices (Auckl). 2011;4:145-55.

71. Anderson WC 3rd, Szefler SJ. New and future strategies to improve asthma control in children. J Allergy Clin Immunol. 2015;136:848-59.

72. Buels KS, Fryer AD. Muscarinic receptor antagonists: effects on pulmonary function. Handb Exp Pharmacol. 2012;208:317-41.

73. Barnes P. Muscarinic receptor subtypes in airways. Eur Respir J. 1993;6:328-31. 